\title{
THE NEPAL CHILDREN'S ORGANIZATION AND THE NEEDS OF THE CHILDREN OF NEPAL
}

\author{
by \\ Mrs. Uma Panday
}

The Nepal Children's Organization is one of the class organizations of the coudry and is the modern agency entrusted 10 carsy out Child Welfure Programmes in the country.

Her Majesiy the Queen has kindly graced the Chairmanship of this organization. Her Royal Highnesses, Cabiner Mintisiers and varieus distinguished piersons from differeot walks of life are members of the Central Conmittee: The Nepal Childrea's Organizaticn was established in August 1964.

It cirries out many programmes for the physical, intellectual and mental development of the children. The Nepal Children's Organization develops the potentiality of all children in literature. music. sports and cultural prostammes. The Bal-Mradir (CHILEREN'S HOME) is the Centre for ill types of extracuricular free time activity of the childrea.

There is ilso an ORPHANAGE, which looks after 150 abandoned children. Besides providing tbem. with food, clothing, shelter and proteciloo of their health, it also prepatts them for a vocation for lite,

A BEGGAR REHABIITATION HOME has aiso been eslablisbed wich bas 50 helnliss children who are given general education and vocetional training like carpentry, talloring ete. A MODEL SCHOOL and also a DEAF SCHOOL have also been run by Nepal Children's Orgnaizition. The deaf school is the only one of its kiad in the counary. A.CHILDREN'S MAGAZINE called 'Balak' (the Cbild) is published every month by this organiza'ion which is distributed to the 5000 sethools all over the kingdom.

The Central Office and the Central Bul Mandir of Nepul Children's Organization has been underiaking these activities.

a Serretary, Nepol Children's Organization, Kathmands. 
THE DISTRICT COMMITTEES apart from the central effice: There are 61 Distriet Committees of Nepal Children's Organization. Eight of these Committees have constructed local Bal Mandirs out of their own funds. They are runing extacurricular activities and PRESCHOOL PROGRAMMES for the children. Twentyfive district committees are running pre-schools programmes for their children. The funds are greatly mobitised by the local people themselves.

\section{THE NATIONAL CONFERENCE}

The Nepal Children's Organization held its national conference last year and outlined future programmes in Child Health, Education, Vocational training and Organization. It was well represented by the Central Committee, the experts from various Gelds and the delegates from the district committes The Government and the UNICEF supported the Nepal Children's Organization and have promised to assess it.

\section{THE NEEDS OF THE CHILDREN}

A look into the Census of Nepal shows that 40 to 50 percent of the population consists of the children. The growth of population is 52 per 1000 , and the general fertillty rate is 50 per 1000 . The crude death rate, is 27 per 1000, and the infant mortality rate is 240 per 1000. Cbildren uoder 4 years of age consist 15 per cent of the total population. Clearly the lafant Mortality Rate is very high. Again 79 per cent of infants die in the first year of life and the death rate gradually decreases as the child grows up thus leading to 40 per cent derth rate by 4 years of age.

The health situation is far from s:tisfactory. Lack of environmental sanitation, and unprotected water-supply result in many infectious diseases carried by food and water. Overcrowded dwellings, flies, \& rats further aggravate the situation. Again low income 'of the common man oftan leads to malnutrition of the infant.

Moreover only 30 per cent of the children are in school. Thus an alarming rate of population are growing up without any preparation for life which is naturally a waste of human resources. Our economy simply cannot aftord tbis. Also Child Labour has gone by unproterted so.far.

\section{THE NEW PLAN OF NEPAL CHILDREN'S ORGANIZATION}

Kceping in view all these conditions the Nepal Cbildren's Organization bas made a new plan for the pre-scbool cbildreo. The UNICEF is also asisting it. This is populaly ralled the COMPREHENCE. -INTEGRATED TYPE OF PRE-SCHOOL PROGRAMME to be inplemeoted on a oational scale. It aims to meet the needs of the child as a cotal persọn. 
The life of the child andsy six is most valuerable to sociol and haalth hozatds. Simn the mojority of those children live in villagus, and are daprived of misimun heolth and nutrition, assistance to them is an investment in human resources.

The programme takes the national need into consideration and bas outlined healtb, nutrition and educational objectives.

The District Committees of Nepal Chlldren's Organization are requested to seek the belp of Maternal and Child Health centres for healtb. The aim is to inmunise the child against Stallpox, Tuburculosis, Telanus, Diphtheria, Whooping Cough and Poliomyelitis. This will be a joit venture of Nepal Children's Organization and the Ministry of Health with a view to teach as mony childroo as possible.

Local people aro encouraged to improve ENVIROMMENTAL SANITATION. Some HEALTH FOUCATION to the community is also to be given. The existing health service of the country should be utilised 10 the maximum. The poor family where INFANT MALNUTRITION often occurs will recieve powdered milk. This will be made avait:able by the W. F.P.

The educational and physical development of these cbildren will be met by improving play and recreational centres for the preschool children. Obviously for these activities the participation of the community and the involvement of the DISTRICT PANCHAYAT is the bisic requisite of the progtanme. These centres for cbildren will meet some of the basic needs of the ebildren of Nepal. 